\title{
PENGEMBANGAN APLIKASI INFO LAGU NUSANTARA BERBASIS ANDROID UNTUK MELESTARIKAN WARISAN BUDAYA INDONESIA
}

\author{
Agus Purnomo \\ Fakultas MIPA, Program Studi D3 Teknik Informatika \\ Universitas Sebelas Maret \\ Email: agus.purnomo@staff.uns.ac.id \\ Rudi Hartono \\ Fakultas MIPA, Program Studi D3 Teknik Informatika \\ Universitas Sebelas Maret \\ Email: rudi.hartono@staff.uns.ac.id \\ Hartatik \\ Fakultas MIPA, Program Studi D3 Teknik Informatika \\ Universitas Sebelas Maret \\ Email: hartatik119@staff.uns.ac.id \\ Berliana Kusuma Riasti \\ Fakultas MIPA, Program Studi D3 Teknik Informatika \\ Universitas Sebelas Maret \\ Email: berliana@staff.uns.ac.id \\ Insani Nur Hidayah \\ Fakultas MIPA, Program Studi D3 Teknik Informatika \\ Universitas Sebelas Maret \\ Email: insaninurhidayah@student.uns.ac.id
}

\begin{abstract}
ABSTRAK
Lagu nusantara merupakan warisan kekayaan budaya Indonesia. Pengenalan lagu nusantara sudah banyak dilakukan melalui pendidikan sekolah dasar sampai pendidikan menengah atas. Upaya ini dilakukan untuk melestarikan budaya Indonesia. Dalam pengenalan terhadap siswa banyak ditemukan kendala yaitu sulitnya siswa menghafal lirik dan menyanyikan berbagai lagu nusantara. Siswa belajar dari buku yang hanya menyediakan liriknya saja dan cara menyanyikan masih harus dibimbing oleh guru seni musik mereka. Untuk mempermudah siswa belajar, maka perlunya media yang mempermudah siswa untuk belajar. Teknologi yang dibahas pada penelitian ini adalah teknologi pemanfaatan smartphone berbasis android untuk memudahkan siswa dalam belajar lagu nusantara. Metode pengembangan aplikasi meliputi studi literatur, analisis, perancangan, pemprograman dan pengujian. Aplikasi dirancang dapat berjalan di perangkat android dengan operating sytem versi ics atau lebih terbaru. Model aplikasi yang dibuat berupa model client-server. Aplikasi client diperuntukan bagi pengguna yaitu siswa dan aplikasi server diperuntukkan untuk update info lagu nusantara yang dilakukan oleh administrator. Aplikasi yang dikembangkan menyajikan informasi lagu nusantara disetiap daerah berupa lirik lagu, suara pelantunanya dan video. Aplikasi info lagu nusantara dinilai mampu menjadikan media pembelajaran bagi siswa dalam mempelajari lagu-lagu nusantara hal ini dibuktikan dengan $78 \%$ responden menjawab setuju dari total responden 19 orang pengguna. 78\% pengguna menganggap aplikasi info lagu nusantara memiliki tampilan yang menarik, susunan navigasi yang mudah, menyajikan informasi yang mudah dipahami,informatif dan edukatif.
\end{abstract}

Kata kunci: aplikasi android, lagu nusantara, media pembelajaran.

\begin{abstract}
Songs archipelago is a legacy of the cultural richness of Indonesia. The introduction of the archipelago song has been done through primary school education to upper secondary education. This effort to preserve the culture of Indonesia. In the introduction to the many students found difficult obstacles that students memorize the lyrics and sang various songs archipelago. Students learn from a book that only provide only the lyrics and sing the way they should be guided by their musical art teacher. To facilitate student learning, the need for media that facilitate students to learn. The
\end{abstract}


technologies covered in this study is the use of technology-based android smartphone to help students learn the song archipelago. Method of application development include a literature study, analysis, design, programming and testing. Applications designed to run on an android device with the operating sytem ics or more of the latest version. Model application made in the form of client-server model. The client application is intended for users, namely students and application server intended to update the info archipelago songs performed by the administrator. Applications developed to present information in each area of the archipelago song in the form of song lyrics, voice and video pelantunanya. Applications song info archipelago is considered capable of making medium of learning for students in learning songs archipelago this is evidenced by 78\% of respondents approve of the total respondents 19 users. $78 \%$ of users consider applications for track info archipelago has an attractive appearance, easy navigation arrangement, present information that is easy to understand, informative and educative.

Keywords: android apps, songs archipelago, instructional media.

\section{PENDAHULUAN}

Lagu nusantara merupakan warisan kekayaan budaya Indonesia. Hampir disetiap daerah memiliki lagu daerah sendiri. Lagu daerah memuat tentang kehidupan masyarakat setempat. Lagu daerah banyak dilantunkan pada acara adat atau acara hiburan rakyat. Lagu daerah juga disebut sebagai lagu rakyat. Lagu daerah memiliki ciri unik dan berbeda dengan masing-masing daerah. Gaya bahasa dalam lirik lagunya sesuai dengan susunan bahasa masing-masing daerah. Lagu nusantara meliputi lagu anak-anak, lagu daerah dan lagu kebangsaan. Lagu nusantara diwariskan turun-temurun dari generasi-kegenerasi yang dikemas dalam kegiatan budaya. Seiring berkembangnya jaman lagu nusantara masuk dalam kurikulum pendidikan dari jenjang pendidikan dasar sampai pendidikan menengah atas. Upaya ini dilakukan untuk melestarikan budaya Indonesia agar tidak hilang oleh tumbuhnya budaya modern. Dalam pembelajaran terhadap siswa banyak ditemukan kendala yaitu sulitnya siswa mengahafal lirik dan menyanyikan berbagai lagu nusantara. Hal ini disebabkan karena belum tersedianya media pembelajaran yang tepat dan menarik bagi siswa. Siswa belajar dari buku yang hanya menyediakan liriknya saja dan cara menyanyikan masih harus dibimbing oleh guru seni musik mereka. Untuk mempermudah siswa belajar, maka perlunya media yang mempermudah siswa untuk belajar. Teknologi berbasis mobile seperti smartphone menjadi pilihan yang bisa digunakan untuk memecahkan masalah ini.

Penggunaan smartphone di Indonesia terus meningkat disetiap tahunnya, mencapai peringkat kelima terbesar di dunia dalam penggunaan smartphone[1]. Pengguna smartphone banyak didominasi oleh anak-anak, kalangan muda dan orang yang bergerak didunia perdagangan dan perkantoran. Aplikasi yang berjalan pada smartphone sudah menjadi bagian dari kehidupan mereka. Aplikasi yang berjalan ini meliputi aplikasi game, aplikasi keuangan, aplikasi sosial media, aplikasi media masa dan sebagainya. Menggabungkan teknologi smartphone dan aplikasi pembelajaran dapat digunakan untuk memecahkan masalah siswa dalam mempelajari dan mengenal lagu nusantara lebih mudah dan menyenangkan.

Berdasarkan permasalahan yang didapat, dalam penelitian ini akan dilakukan pengembangan aplikasi pembelajaran yang berupa aplikasi berbasis android yang mampu berjalan pada perangkat smartphone. Aplikasi ini akan memuat info lagu nusantara yang memudahkan siswa dalam mempelajari lagu setiap daerah yang ada di Indonesia.

\section{METODOLOGI PENELITIAN}

Metodologi penelitian yang dilakukan dalam pengembangan aplikasi info lagu nusantara adalah sebagai berikut:

a. Studi pustaka dan pengumpulan data, langkah ini dilakukan untuk mengetahui kategori lagu nusantara dan pengumpulan semua lirik lagu, file $\mathrm{mp} 3$ dan video dari setiap lagu;

b. Analisis, langkah ini digunakan untuk mengetahui model aplikasi, komponen pendukung dan alat yang nantinya dibutuhkan dalam pembuatan aplikasi;

c. Perancangan, perancangan meliputi perancangan tampilan, tataletak menu, tombol navigasi, dan perancangan proses bisnis sistem;

d. Pemprograman, penulisan kode program yang akan dieksekusi oleh komputer;

e. Pengujian, melakukan pengujian dari aplikasi yang dibuat sebelum diimplementasikan. Pengujian meliputi fungsionalitas sistem. 


\subsection{Tinjauan Pustaka}

Penelitian tentang pelestarian lagu nusantara dan pengembangan aplikasi lagu nusantara sudah banyak dilakukan oleh peneliti sebelumnya yaitu: aplikasi kumpulan lagu daerah [2] , aplikasi lagu anakanak berbahasa Indonesia [3], aplikasi lagu-lagu wajib [4] , Perangkat ajar alat musik dan lagu tradisonal Indonesia [5], meningkatkan aktivitas dan hasil belajar apresiasi musik nusantara melalui penggunaan lagu model pada siswa kelas 8A smp negeri 1 pangkah, kabupaten tegal [6], penerapan metode drilluntuk meningkatkan keterampilan menyanyikan lagu daerahnusantara siswasmp [7]. Dari semua aplikasi tersebut memiliki konsep yang sama yaitu memudahkan dalam pencarian atau pengenalan tentang lagulagu nusantara, perbedaanya adalah memuat isi yang berbeda dan lebih spesifik dari setiap kategori lagu nusantara. Aplikasi yang dikembangkan dalam penelitian ini secara garis besar adalah menggabungkan dari setiap model atau kategori dari aplikasi yang sudah ada. Aplikasi yang dibuat menampilkan 4 kategori lagu dalam satu aplikasi yaitu memuat lagu nasional atau lagu wajib, lagu daerah, lagu dolanan atau anak-anak, dan macapat. Pada aplikasi yang dibuat terdapat fitur info lagu, audio, video, dan fitur pencarian. Untuk fitur audio dan video, lagu dapat langsung dimainkan dan diputar tanpa harus mengunduh terlebih dahulu ke internet. Pada fitur pencarian terdapat 2 kategori yaitu pencarian berdasarkan judul dari semua kategori lagu dan pencarian berdasarkan asal daerah untuk kategori lagu daerah.

\subsection{Dasar Teori}

Lagu adalah hasil karya musik berupa rangkaian nada-nada dan syair yang disusun untuk mengungkapkan pikiran dan perasaan penciptanya. Lagu nusantara adalah lagu yang tumbuh dan berkembang di wilayah nusantara [8]. Beberapa kategori lagu nusantara adalah sebagai berikut:

a. Lagu dolanan atau lagu anak-anak

Lagu dolanan atau lagu anak-anak adalah lagu yang bentuknya sederhana dan kalimatnya tidak terlalu panjang dan mengandung unsur permainan dan pembelajaran.Temanya sesuai dengan jiwa anak-anak, bahasanya sederhana dan mudah dimengerti, tidak terlalu banyak menggunakan kiasan [9].

b. Lagu daerah

Lagu Daerah adalah lagu yang lahir dari budaya daerah setempat yang bersifat turun-temurun. Bahasa dan dialek lagu daerah yang digunakan tersebut kadang-kadang sulit untuk diketahui maksud dan tujuan yang ada dalam lagu daerah [10].

c. Lagu kebangsaan atau lagu nasional

Lagu Kebangsaan adalah suatu lagu yang diakui menjadi lagu resmi dan menjadi simbol suatu negara atau daerah. Lagu kebangsaan dapat membentuk identitas nasional suatu negara dan dapat digunakan sebagai ekspresi dalam menunjukkan nasionalisme dan patriotisme [10].

d. Lagu mocopat

Mocopat adalah bentuk puisi Jawa tradisional, setiap baitnya mempunyai baris kalimat (gatra) tertentu, setiap gatra mempunyai jumlah suku kata (guru wilangan) tertentu, dan berakhir pada bunyi sajak akhir (guru lagu; guru suara tertentu) [10].

\subsection{Perancangan Aplikasi}

Aplikasi info lagu nusantara dirancang memuat informasi lirik lagu, audio dan video dari setiap lagu. Ada 4 kategori yang akan disampaikan yaitu lagu dolanan atau lagu anak-anak, lagu daerah, lagu nusantara dan lagu mocopat. Aplikasi info lagu dibuat dengan model client-server. Aplikasi client dipakai oleh pengguna dan aplikasi server digunakan untuk update data informasi lagu nusantara. Aplikasi client memuat tentang informasi lagu nusantara yang mengambil data dari database diposisi aplikasi server. Aplikasi client berbasis aplikasi android dan aplikasi server berbasis aplikasi web. Model komunikasi antara aplikasi client dan aplikasi server ditunjukkan pada Gambar 1. 


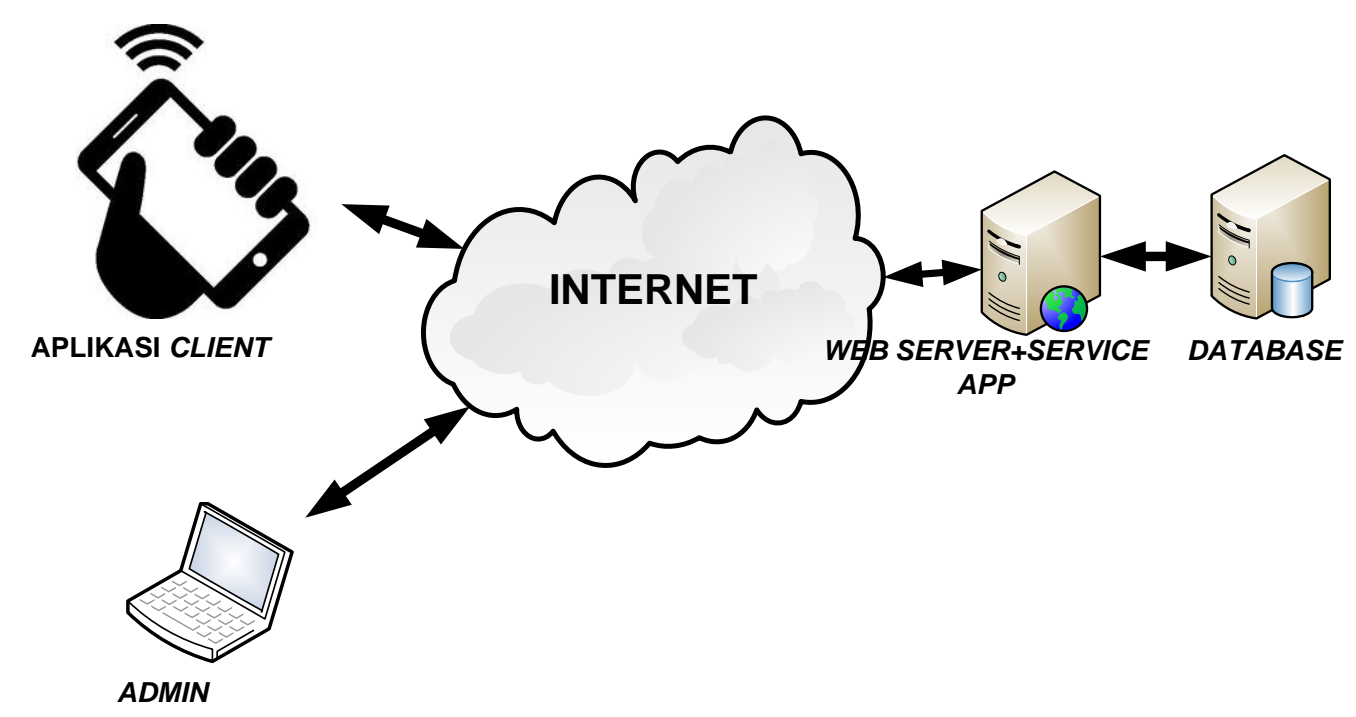

Gambar 1. Model Komunikasi Antara Aplikasi Client Dan Aplikasi Server

\subsubsection{Kebutuhan Fungsional Sistem}

Kebutuhan Sistem Informasi aplikasi ini meliputi Functional System Info Lagu (yang selanjutnya ditulis FSIL) dan Non Functional System Info Lagu (yang selanjutnya ditulis NFSIL). FSIL berkaitan langsung dengan kebutuhan sistem sedangkan NFSIL berkaitan dengan hal yang tidak berkaitan langsung dengan sistem seperti kebutuhan perangkat yang digunakan dan lain-lain.

Sistem ini akan digunakan oleh dua user, yaitu server dan client. Pada Tabel 1 akan menjelaskan spesifikasi akses dari user tersebut.

Tabel 1. Deskripsi user

\begin{tabular}{ccc}
\hline No & Nama & Deskripsi \\
\hline 1 & Admin & Orang yang bertanggung jawab untuk mengelola data aplikasi. \\
2 & Client & Orang yang menggunakan aplikasi. \\
\hline
\end{tabular}

Sistem ini memiliki beberapa kebutuhan fungsional. Pada Tabel 2 akan dijelaskan beberapa kebutuhan fungsional yang dimiliki sistem info lagu nusantara.

Tabel 2. Functional system info lagu

\begin{tabular}{|c|c|c|c|}
\hline Kode & Judul & Deskripsi & User \\
\hline FSIL-01 & $\begin{array}{l}\text { View lagu } \\
\text { nasional }\end{array}$ & $\begin{array}{l}\text { System dapat menampilkan data lagu yang termasuk } \\
\text { lagu nasional }\end{array}$ & Client \\
\hline FSIL-02 & $\begin{array}{l}\text { View lirik lagu } \\
\text { nasional }\end{array}$ & $\begin{array}{l}\text { System dapat menampilkan lirik lagu dari tiap-tiap lagu } \\
\text { nasiona }\end{array}$ & Client \\
\hline FSIL-03 & $\begin{array}{c}\text { Play lagu } \\
\text { nasional }\end{array}$ & System dapat memutar tiap-tiap lagu nasional & Client \\
\hline FSIL-04 & $\begin{array}{l}\text { Play video lagu } \\
\text { nasional }\end{array}$ & $\begin{array}{l}\text { System dapat memutar video tiap-tiap data lagu } \\
\text { nasional }\end{array}$ & Client \\
\hline FSIL-05 & $\begin{array}{l}\text { Search lagu } \\
\text { nasional }\end{array}$ & $\begin{array}{l}\text { System dapat mencari data lagu nasional berdasarkan } \\
\text { judul lagu nasional }\end{array}$ & Client \\
\hline FSIL-06 & View lagu daerah & System dapat menampilkan data lagu daerah & Client \\
\hline FSIL-07 & $\begin{array}{c}\text { View lirik lagu } \\
\text { daerah }\end{array}$ & System dapat menampilkan lirik lagu daerah & Client \\
\hline FSIL-08 & Play lagu daerah & System dapat memutar tiap-tiap lagu daerah & Client \\
\hline FSIL-09 & $\begin{array}{l}\text { Play video lagu } \\
\text { daerah }\end{array}$ & $\begin{array}{l}\text { System dapat memutar video masing-masing lagu } \\
\text { daerah }\end{array}$ & Client \\
\hline FSIL-10 & $\begin{array}{l}\text { Search lagu } \\
\text { daerah }\end{array}$ & $\begin{array}{l}\text { System dapat mencari lagu daerah berdasarkan judul } \\
\text { dan daerah asal }\end{array}$ & Client \\
\hline FSIL-11 & $\begin{array}{l}\text { View lagu } \\
\text { dolanan }\end{array}$ & $\begin{array}{l}\text { System dapat menampilkan data lagu yang termasuk } \\
\text { lagu dolanan }\end{array}$ & Client \\
\hline
\end{tabular}




\begin{tabular}{|c|c|c|c|}
\hline Kode & Judul & Deskripsi & User \\
\hline FSIL-12 & $\begin{array}{l}\text { View lirik lagu } \\
\text { dolanan }\end{array}$ & $\begin{array}{l}\text { System dapat menampilkan lirik lagu dari tiap-tiap lagu } \\
\text { dolanan yang ada }\end{array}$ & Client \\
\hline FSIL-13 & $\begin{array}{l}\text { Play lagu } \\
\text { dolanan }\end{array}$ & System dapat memutar masing-masing lagu dolanan & Client \\
\hline FSIL-15 & $\begin{array}{l}\text { Play video lagu } \\
\text { dolanan }\end{array}$ & $\begin{array}{l}\text { System dapat memutar video masing-masing lagu } \\
\text { daerah }\end{array}$ & Client \\
\hline FSIL-16 & $\begin{array}{l}\text { Search lagu } \\
\text { dolanan }\end{array}$ & $\begin{array}{l}\text { System dapat mencari data lagu dolanan berdasarkan } \\
\text { judulnya }\end{array}$ & Client \\
\hline FSIL-17 & $\begin{array}{l}\text { View tembang } \\
\text { macapat }\end{array}$ & $\begin{array}{l}\text { System dapat menampilkan data lagu yang termasuk } \\
\text { tembang macapat }\end{array}$ & Client \\
\hline FSIL-18 & $\begin{array}{l}\text { View lirik } \\
\text { tembang macapat }\end{array}$ & $\begin{array}{l}\text { System dapat menampilkan lirik lagu dari tiap-tiap } \\
\text { tembang macapat yang ada }\end{array}$ & Client \\
\hline FSIL-19 & $\begin{array}{l}\text { Play tembang } \\
\text { macapat }\end{array}$ & $\begin{array}{l}\text { System dapat memutar masing-masing tembang } \\
\text { macapat }\end{array}$ & Client \\
\hline FSIL-20 & $\begin{array}{l}\text { Pencarian } \\
\text { tembang macapat }\end{array}$ & $\begin{array}{l}\text { System dapat mencari data lagu macapat berdasarkan } \\
\text { judulnya }\end{array}$ & Client \\
\hline FSIL-21 & Daftar kuis & System menyediakan pendaftaran permainan kuis & Client \\
\hline FSIL-22 & View soal kuis & $\begin{array}{l}\text { System dapat menampilkan soal-soal kuis yang } \\
\text { bertemakan tentang lagu nusantara }\end{array}$ & Client \\
\hline FSIL-23 & Acak soal kuis & System dapat mengacak urutan kuis & Admin \\
\hline FSIL-24 & $\begin{array}{l}\text { Input lagu } \\
\text { nasional }\end{array}$ & System dapat menginput lagu nasional & Admin \\
\hline FSIL-25 & $\begin{array}{l}\text { Edit lagu } \\
\text { nasional }\end{array}$ & System dapat mengedit data lagu nasional & Admin \\
\hline FSIL-26 & $\begin{array}{l}\text { Hapus lagu } \\
\text { nasional }\end{array}$ & System dapat menghapus lagu nasional & Admin \\
\hline FSIL-27 & $\begin{array}{l}\text { Input tembang } \\
\text { macapat }\end{array}$ & System dapat menginput tembang macapat & Admin \\
\hline FSIL-28 & $\begin{array}{l}\text { Edit tembang } \\
\text { macapat }\end{array}$ & System dapat mengedit data tembang macapat & Admin \\
\hline FSIL-29 & $\begin{array}{l}\text { Hapus tembang } \\
\text { macapat }\end{array}$ & System dapat menghapus tembang macapat & Admin \\
\hline FSIL-30 & $\begin{array}{l}\text { Input nama } \\
\text { daerah }\end{array}$ & System dapat menginput nama daerah & Admin \\
\hline FSIL-31 & Edit nama daerah & System dapat mengedit data nama daerah & Admin \\
\hline FSIL-32 & $\begin{array}{l}\text { Hapus nama } \\
\text { daerah }\end{array}$ & System dapat menghapus nama daerah & Admin \\
\hline FSIL-33 & $\begin{array}{c}\text { Input kategori } \\
\text { lagu }\end{array}$ & System dapat menginput kategori lagu & Admin \\
\hline FSIL-34 & $\begin{array}{c}\text { Edit kategori } \\
\text { lagu }\end{array}$ & System dapat mengedit data kategori lagu & Admin \\
\hline FSIL-35 & $\begin{array}{c}\text { Hapus kategori } \\
\text { lagu }\end{array}$ & System dapat menghapus kategori lagu & Admin \\
\hline FSIL-36 & Input lagu & System dapat menginput lagu & Admin \\
\hline FSIL-37 & Edit lagu & System dapat mengedit data lagu & Admin \\
\hline FSIL-38 & Hapus lagu & System dapat menghapus lagu & Admin \\
\hline FSIL-39 & Edit pengguna & System dapat mengedit data pengguna & Admin \\
\hline FSIL-40 & Hapus pengguna & System dapat menghapus data pengguna & Admin \\
\hline FSIL-41 & Input jenis kuis & System dapat menginput data jenis kuis & Admin \\
\hline FSIL-42 & Edit jenis kuis & System dapat mengedit data jenis kuis & Admin \\
\hline FSIL-43 & Hapus jenis kuis & System dapat menghapus data jenis kuis & Admin \\
\hline FSIL-44 & Input kuis & System dapat menginput kuis & Admin \\
\hline FSIL-45 & Edit kuis & System dapat mengedit data kuis & Admin \\
\hline FSIL-46 & Hapus kuis & System dapat menghapus data kuis & Admin \\
\hline FSIL-47 & Edit skor & System dapat mengedit data skor & Admin \\
\hline FSIL-48 & Hapus skor & System dapat menghapus skor & Admin \\
\hline
\end{tabular}




\subsubsection{Usecase Diagram}

Berdasarkan pada kebutuhan fungsional dari aplikasi Info Lagu Nusantara dapat diperoleh usecase diagram untuk aplikasi client seperti ditunjukan pada Gambar 2 dan usecase diagram untuk aplikasi server ditunjukan pada Gambar 3.
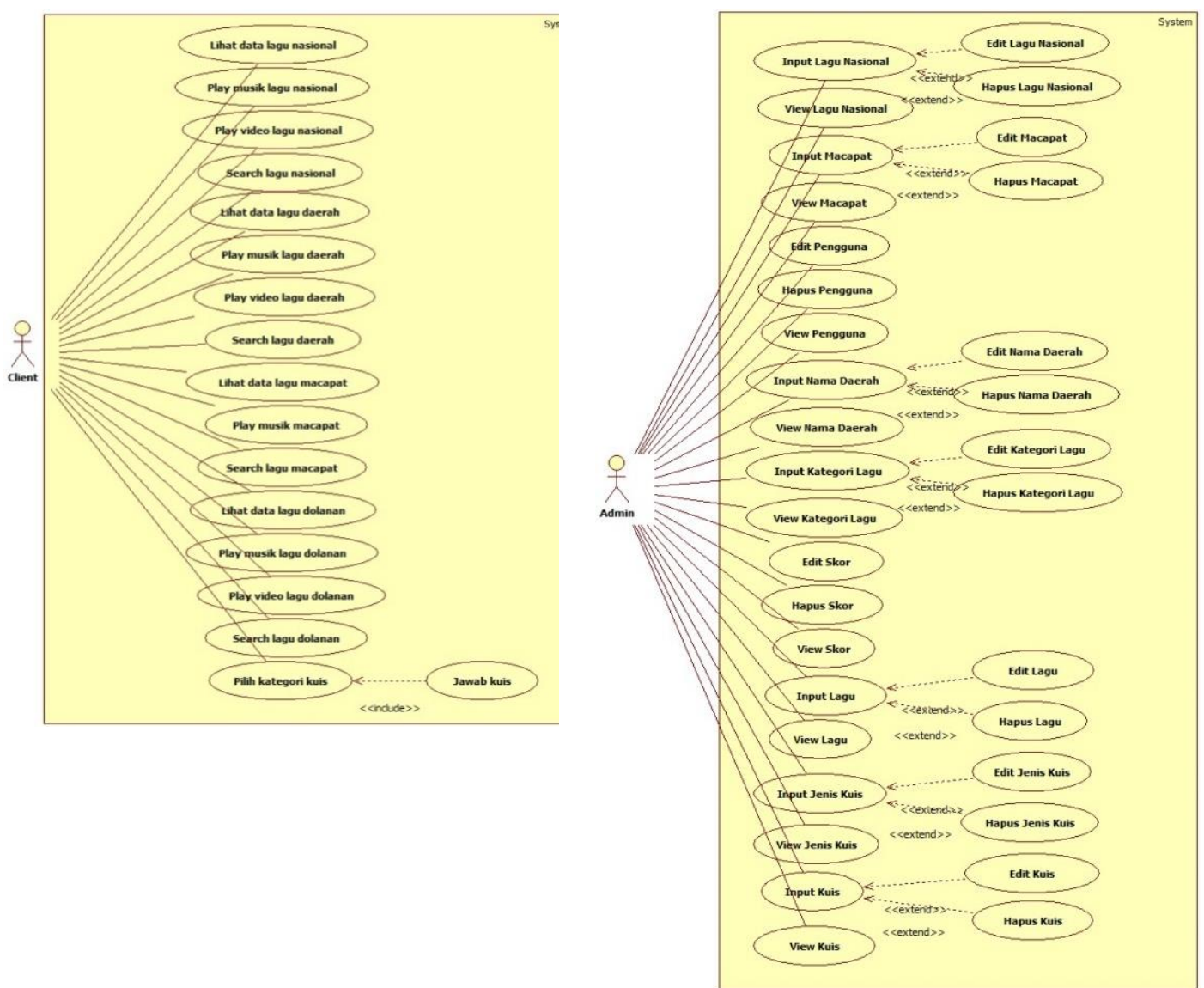

\section{Gambar 2. Usecase Diagram Untuk} Aplikasi Client

Gambar 3. Usecase Diagram Untuk Aplikasi Server

\section{HASIL DAN PEMBAHASAN}

Aplikasi yang berhasil dikembangkan bermodel client-server artinya terdapat aplikasi yang berkeja di sisi client dan terdapat aplikasi yang bekerja disisi server. Aplikasi client menyajikan informasi tentang lagu nusantara yang diperuntukan bagi pengguna. Sedangkan aplikasi server menyajikan fasilitas untuk melakukan update data info lagu nusantara yang berupa diskripsi dari masing masing lagu, lirik lagu, upload file lagu dengan format $m p 3$ dan link video dari setiap lagu.

\subsection{Hasil Dari Aplikasi Client}

Tampilan dan fasilitas yang disajikan pada aplikasi client info lagu nusantara ditunjukan pada Gambar 4. Selain informasi tentang lagu nusantara yang berupa info lagu dolanan atau lagu anak-anak, lagu daerah, lagu nasional dan lagu mocopat, aplikasi client juga menyajikan permainan semacam quiz. Quiz merupakan fasilitas yang diperuntukan untuk menguji pengguna tentang penguasaan materi atau pengetahuan yang telah didapat. 

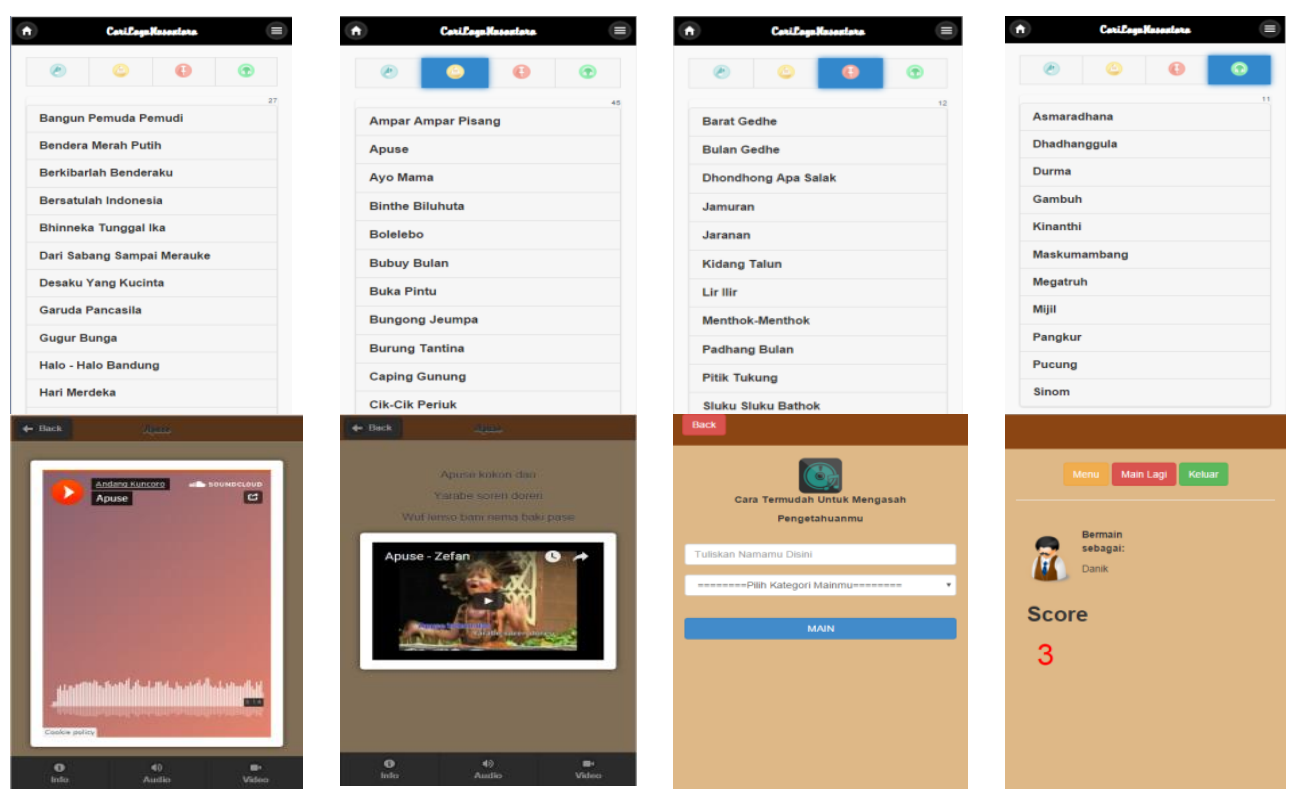

Gambar 4. Tampilan Dan Fasilitas Aplikasi Client Info Lagu Nusantara Ditunjukan

\subsection{Hasil Dari Aplikasi Server}

Tampilan dan fasilitas yang disajikan pada aplikasi server info lagu nusantara ditunjukan pada Gambar 5. Menyajikan menu tambah lagu dari setiap kategori, tambah daftar nama daerah, update soal quiz, dan pengaturan umum seperti seting akun dan password.

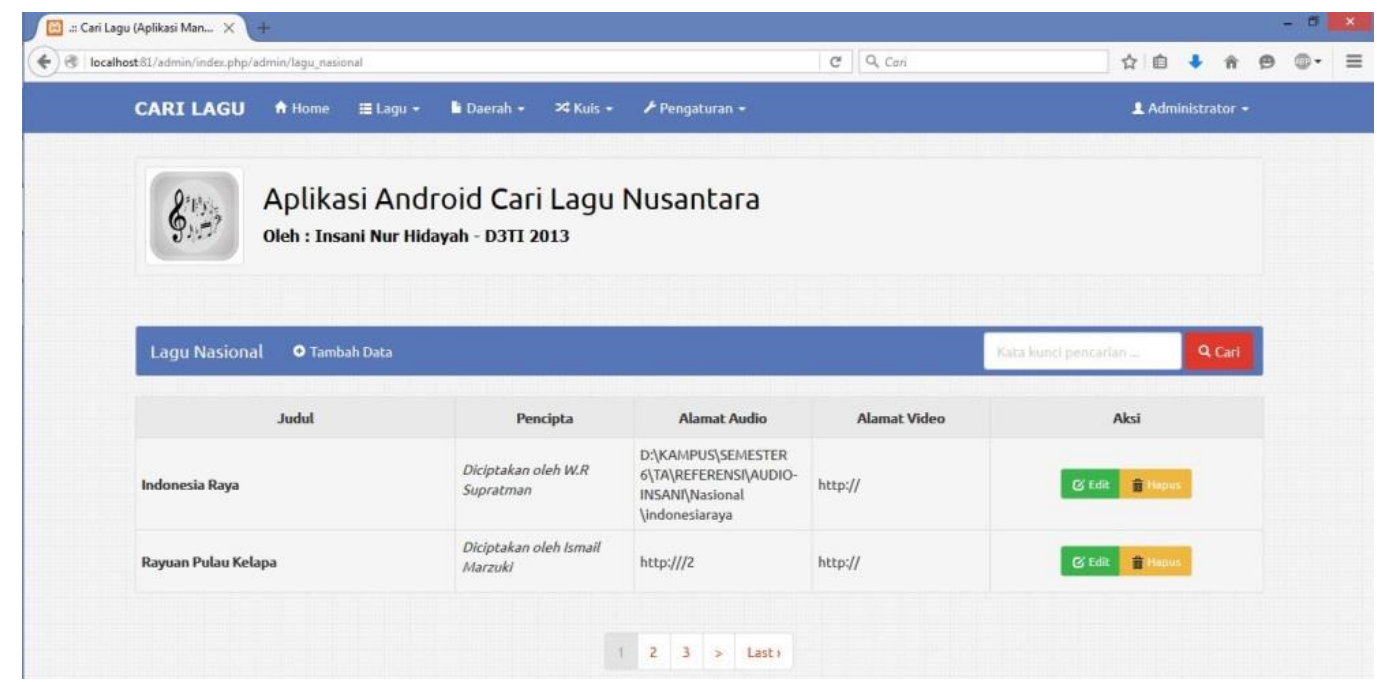

Gambar 5. Tampilan Dan Fasilitas Aplikasi Server Info Lagu Nusantara Ditunjukan

\subsection{Pengujian Dengan Metode Blackbox}

Untuk mendapatkan informasi performa dari aplikasi info lagu nusantara maka dilakukan pengujian. Teknik pengujian yang dilakukan adalah dengan teknik pengujian blackbox. Teknik pengujian blackbox itu sendiri adalah pengujian untuk menemukan kesalahan dalam beberapa kategori, diantaranya: fungsifungsi yang salah atau hilang, kesalahan interface, kesalahan dalam struktur data atau akses database eksternal, kesalahan performa, kesalahan inisialisasi dan terminasi [11] . Perangkat keras yang digunakan untuk pengujian ditunjukan pada Tabel 3. 
Tabel 3. Daftar perangkat keras untuk pengujian

\begin{tabular}{ccc}
\hline Spesifikasi & Samsung Galaxy Vplus & Tablet Advan C1E+ \\
\hline OS & v4.4.2(Kitkat) & 4.2 Jelly Bean \\
CPU & Dual-core $1.2 \mathrm{GHz}$ & Cortex A7Dual core $1.3 \mathrm{GHz}$ \\
Internal Storage & $512 \mathrm{MB}$ & $512 \mathrm{MB}$ \\
Screen & $4.0 " W v g a(480 \times 800)$ & 7 inch \\
\hline
\end{tabular}

Pengujian dilakukan dengan cara membuat tabel check list yang berisi daftar fungsi-fungsi pada aplikasi kemudian diuji satu persatu lalu diberikan keterangan mengenai hasil test. Data hasil pengujian dapat dilihat pada Tabel 4.

Tabel 4. Daftar data hasil pengujian blackbox

\begin{tabular}{|c|c|c|c|c|c|}
\hline \multirow{2}{*}{ No. } & \multirow{2}{*}{ Fungsi } & \multirow{2}{*}{ Jenis } & \multirow{2}{*}{ Hasil yang diharapkan } & \multicolumn{2}{|c|}{ Hasil } \\
\hline & & & & Samsung & Tablet \\
\hline 1. & $\begin{array}{l}\text { Instalasi } \\
\text { apk }\end{array}$ & Penginstalan & $\begin{array}{l}\text { Ketika aplikasi diinstal maka icon aplikasi } \\
\text { akan terinstal di handphone }\end{array}$ & $\sqrt{ }$ & $\sqrt{ }$ \\
\hline \multirow[t]{4}{*}{2.} & Scene & Menu utama & $\begin{array}{l}\text { Setelah penginstalan, dan aplikasi mulai } \\
\text { dijalankan maka akan tampil menu utama } \\
\text { yaitu menu lagu nasional dengan list view } \\
\text { judul lagu nasional }\end{array}$ & $\sqrt{ }$ & $\sqrt{ }$ \\
\hline & & $\begin{array}{l}\text { Menu lagu } \\
\text { daerah }\end{array}$ & $\begin{array}{l}\text { Ketika menu lagu daerah disentuh maka } \\
\text { akan muncul list view judul lagu daerah }\end{array}$ & $\sqrt{ }$ & $\sqrt{ }$ \\
\hline & & $\begin{array}{l}\text { Menu lagu } \\
\text { dolanan }\end{array}$ & $\begin{array}{l}\text { Ketika menu lagu dolanan disentuh maka } \\
\text { akan muncul list view judul lagu dolanan }\end{array}$ & $\sqrt{ }$ & $\sqrt{ }$ \\
\hline & & $\begin{array}{l}\text { Menu lagu } \\
\text { macapat }\end{array}$ & $\begin{array}{l}\text { Ketika menu lagu macapat disentuh maka } \\
\text { akan muncul list view judul lagu macapat }\end{array}$ & $\sqrt{ }$ & $\sqrt{ }$ \\
\hline \multirow[t]{3}{*}{2.} & Fitur & Audio & $\begin{array}{l}\text { Ketika salah satu judul lagu dipilih, } \\
\text { selanjutnya akan ada menu pilihan yaitu } \\
\text { audio, info, dan video. Ketika audio dipilih } \\
\text { maka akan menampilkan audio lagu yang } \\
\text { telah dipilih }\end{array}$ & $\sqrt{ }$ & $\sqrt{ }$ \\
\hline & & Video & $\begin{array}{l}\text { Ketika salah satu judul lagu dipilih, } \\
\text { selanjutnya akan ada menu pilihan yaitu } \\
\text { audio, info, dan video. Ketika video dipilih } \\
\text { maka akan menampilkan video dari lagu } \\
\text { yang telah dipilih }\end{array}$ & $\sqrt{ }$ & $\sqrt{ }$ \\
\hline & & Info & $\begin{array}{l}\text { Ketika salah satu judul lagu dipilih, } \\
\text { selanjutnya akan ada menu pilihan yaitu } \\
\text { audio, info, dan video. Ketika info dipilih } \\
\text { maka akan menampilkan info lagu yang } \\
\text { telah dipilih }\end{array}$ & $\sqrt{ }$ & $\sqrt{ }$ \\
\hline \multirow[t]{3}{*}{3.} & Quis & Main menu & $\begin{array}{l}\text { Ketika menu kuis disentuh, maka akan } \\
\text { menampilkan kolom username, dan } \\
\text { pilihan kategori main }\end{array}$ & $\sqrt{ }$ & $\sqrt{ }$ \\
\hline & & Soal & $\begin{array}{l}\text { Setelah mengisi username dan memilih } \\
\text { kategori dan mengklik main maka akan } \\
\text { muncul soal-soal kuis }\end{array}$ & $\sqrt{ }$ & $\sqrt{ }$ \\
\hline & & Skor & $\begin{array}{l}\text { Setelah menjawab soal maka akan muncul } \\
\text { skor yang diperoleh }\end{array}$ & $\sqrt{ }$ & $\sqrt{ }$ \\
\hline \multirow[t]{2}{*}{4.} & Pencarian & $\begin{array}{l}\text { Berdasarkan } \\
\text { judul }\end{array}$ & $\begin{array}{l}\text { Ketika memilih menu pencarian } \\
\text { berdasarkan judul maka ketika client } \\
\text { mengetikan keyword akan muncul data } \\
\text { yang cari jika keyword benar }\end{array}$ & $\sqrt{ }$ & $\sqrt{ }$ \\
\hline & & $\begin{array}{l}\text { Berdasarkan } \\
\text { daerah }\end{array}$ & $\begin{array}{l}\text { Ketika memilih menu pencarian } \\
\text { berdasarkan daerah maka ketika client } \\
\text { mengetikan keyword akan muncul data } \\
\text { yang cari jika keyword benar }\end{array}$ & $\sqrt{ }$ & $\sqrt{ }$ \\
\hline
\end{tabular}




\subsection{Pengujian Dengan Kuesioner}

Pengujian dengan kuesioner dilakukan untuk mengetahui penilaian dari aplikasi info lagu nusantara oleh pengguna. Responden merupakan siswa-siswi kelas VIII dari SMP Negeri 3 Semin dengan jumlah siswa 19 orang. Kuisioner ini terdiri dari 10 butir pertanyaan yang berhubungan dengan konten dari aplikasi info lagu nusantara yang ditunjukan pada Tabel 5. Grafik hasil kuesioner ditunjukan pada Gambar 5.

Tabel 5. Daftar pertanyaan kuesioner

\begin{tabular}{cl}
\hline Nomor & \multicolumn{1}{c}{ Pertanyaan } \\
\hline Kuesioner 1 & Bagaimana tampilan yang disajikan dari aplikasi ini ? \\
Kuesioner 2 & Bagaimana pewarnaan yang diberikan untuk aplikasi ini ? \\
Kuesioner 3 & Bagaimana ikon dan tombol yang disajikan dalam aplikasi ini ? \\
Kuesioner 4 & Apakah aplikasi ini mudah digunakan ? \\
Kuesioner 5 & Apakah audio dan video dalam aplikasi ini terdengar dan terlihat jelas ? \\
Kuesioner 6 & Apakah fitur-fitur dalam aplikasi ini berjalan dengan baik ? \\
Kuesioner 7 & Bagaimana informasi yang disajikan dalam aplikasi ini ? \\
Kuesioner 8 & Apakah dengan aplikasi ini dapat meningkatkan minat anda dalam mengenal lagu \\
& nusantara ? \\
Kuesioner 9 & Apakah dengan aplikasi ini dapat membantu dalam menghafalkan lagu nusantara \\
& ? \\
Kuesioner 10 & Apakah aplikasi ini cocok disebut sebagai aplikasi edukasi ? \\
\hline
\end{tabular}
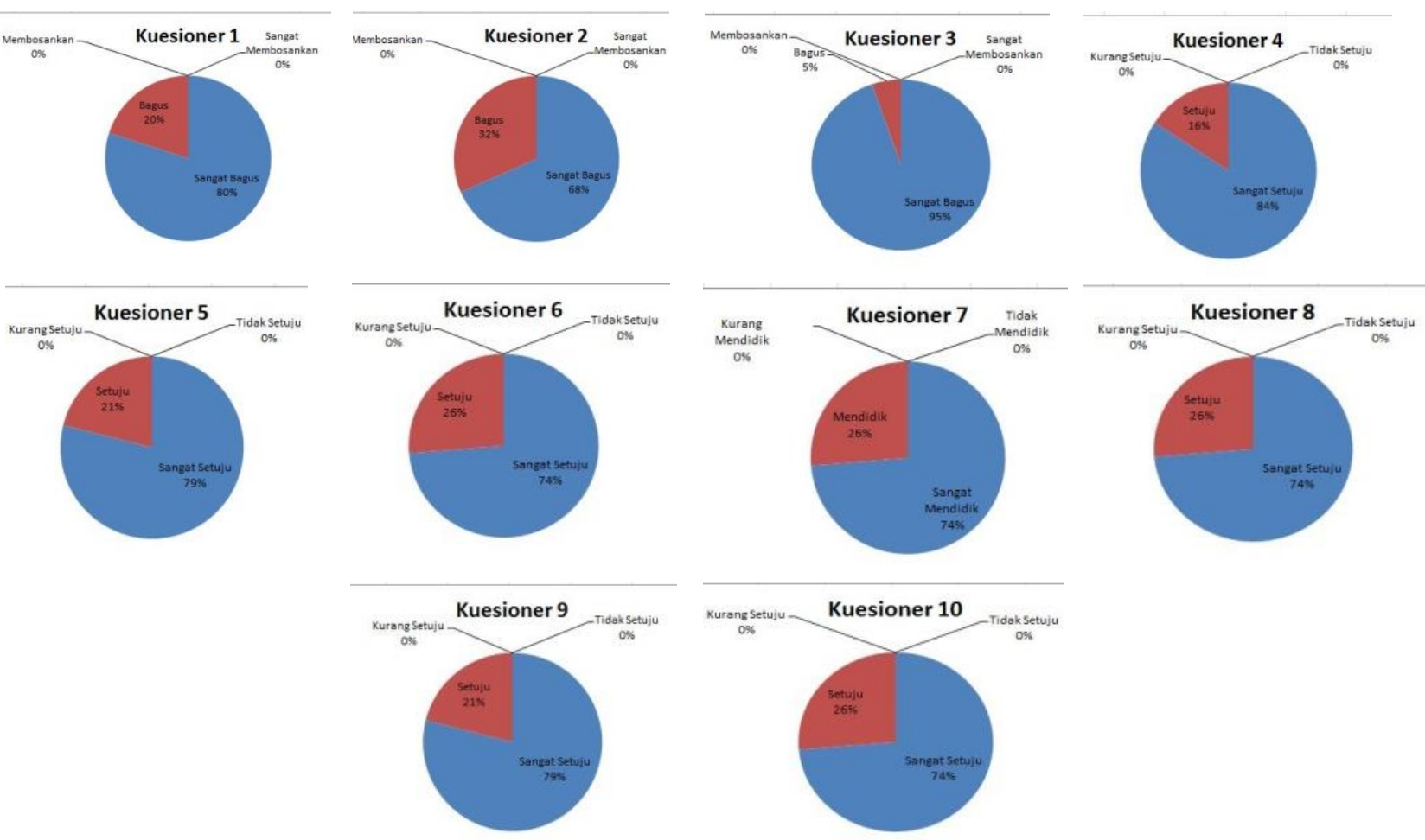

Gambar 5. Grafik Hasil Kuesioner

\section{KESIMPULAN}

Berdasarkan hasil dari penelitian dapat diambil kesimpulan bahwa aplikasi info lagu nusantara mampu menjadikan media pembelajaran bagi siswa dalam mempelajari lagu-lagu nusantara hal ini dibuktikan dengan rata-rata responden menjawab $78 \%$ menjawab setuju dari total responden 19 orang pengguna. $78 \%$ pengguna menganggap aplikasi info lagu nusantara memiliki tampilan yang menarik, susunan navigasi yang mudah, menyajikan informasi yang mudah dipahami,informatif dan edukatif yang memudahkan siswa dapat belajar dengan lebih mudah dalam mempelajari dan menghafal lagu-lagu nusantara yang berupa lagu dolanan, lagu daerah, lagu nasional dan lagu mocopat. Fasilitas quiz juga 
akan lebih mudah dalam mengukur tingkat penguasaan materi. Aplikasi cukup ringat karena mampu dijalankan pada spesifikasi perangkat yang rendah yaitu mulai dari versi android ICS.

\section{UCAPAN TERIMA KASIH}

Penulis mengucapkan terima ksaih untuk Prodi D3 Teknik Informatika FMIPA dan LPPM Universitas Sebelas Maret sebagai tempat pengembangan aplikasi info lagu nusantara dan dukungan dana pengembangan aplikasi dalam skim pengabdian kepada masyarakat (iBM).

\section{DAFTAR PUSTAKA}

[1] Sharen Gifary, "INTENSITAS PENGGUNAAN SMARTPHONE TERHADAP PERILAKU", Jurnal Sosioteknologi, vol. 14, pp. 171-178, 2015.

[2] M Al-Idrus, Pembuatan Aplikasi kumpulan Lagu Daerah Berbasis Android. Yogyakarta: Jurnal Amikom, 2014.

[3] A. Z. Prakatam, Pembuatan Aplikasi Lagu Anak-Anak Berbasis Bahasa Indonesia. Yogyakarta: Jurnal Amikom, 2014.

[4] O. Fajarianto, Aplikasi Lagu-Lagu Wajib Menggunakan Simulasi Gitar Berbasis Animasi 2D Dengan Adobe Flash CS 5. Yogyakarta: STMIK, 2014.

[5] M. Angelina, Perangkat Ajar Alat Musik dan Lagu Tradisional Indonesia Untuk Pendidikan Anak sekolah Dasar Berbasis Multimedia. Jakarta: Universitas Kristen Krida Wacana, 2014.

[6] Ekaningtyas Herminingrum dan Totok Sumaryanto, "MENINGKATKAN AKTIVITAS DAN HASIL BELAJAR APRESIASI MUSIK NUSANTARA MELALUI PENGGUNAAN LAGU MODEL PADA SISWA KELAS VIIIA SMP NEGERI 1 PANGKAH, KABUPATEN TEGAL", Jurnal seni musik unnes, vol 2, no 1. 2013.

[7] Soginem, Imam Ghozali dan Winda Istiandini, "PENERAPAN METODE DRILLUNTUK MENINGKATKAN KETERAMPILAN MENYANYIKAN LAGU DAERAHNUSANTARA SISWASMP”, jurnal pendidikan dan pembelajaran, UNTAN, Vol.4, No.1, 2015.

[8] Setiawan, Indah Fitri Astuti, and Dyna Marisa Khairina, "RANCANG BANGUN GAME EDUKASI BERBASIS ANDROID TEBAK LAGU NUSANTARA: SENARA". Jurnal Informatika Mulawarman, vol. 9, no. 2, p. 24, Juni 2014.

[9] Purwadi and W. Endang, Tembang Dolanan (Lagu-lagu Jawa Disertai dengan Tafsir Maknanya buat Panduan Kehidupan Demi Memperkokoh Jatidiri Bangsa. Yogyakarta: Laras Media Prima, 2015.

[10] KBBI, Kamus besar bahasa Indonesia. Jakarta, 2016.

[11] Zulkifli, "Model Prediksi Berbasis Neural Network untuk Pengujian Perangkat Lunak Metode Black-Box," Journal Ilmiah, 2013. 